Situs Jurnal : $\underline{\text { http://ejournal.stiepancasetia.ac.id/index.php/jieb }}$

Jilid 5 Nomor 3 November 2019

Hal 312 - 326

\title{
ANALISIS PENGELOLAAN KEUANGAN DESA PADA PEMERINTAH DESA PASAR LAMA KECAMATAN KARANG INTAN KABUPATEN BANJAR
}

\section{Hernida dan Yudi Rahman*}

Abstract: This study aims to describe the Analysis of Village Financial Management in the Pasar Lama Village Government in Karang Intan District, Banjar Regency, covering planning, implementation, administration, reporting and accountability of village finance. Know and analyze how the comparison of Village Financial Management according to the format of Banjar Regent Regulation Number 3 of 2017 with Village Financial Management in the Pasar Lama Village Government. This study uses a qualitative research method with a descriptive analysis approach. File collection techniques are carried out by interview, observation, documentation and literature. File analysis uses interactive analysis techniques, namely through collectionfile, reduction file, presentation file and conclusion drawing. The results showed that although there were errors in the administration of the arrangement but overall the financial management of Pasar Lama Village was almost the same as the management according to the format of the Banjar Regent Regulation Number 3 of 2017

Keywords: village financial management, Pasar Lama Village government, Karang Intan District

Abstrak: Penelitian ini bertujuan untuk mendeskripsikan Analisis Pengelolaan Keuangan Desa Pada Pemerintahan Desa Pasar Lama Kecamatan Karang Intan Kabupaten Banjar meliputi perencanaan, pelaksanaan, penatausahaan, pelaporan dan pertanggungjawaban keuangan desa. Mengetahui dan menganalisis bagaimana perbandingan Pengelolaan Keuangan Desa menurut format Peraturan Bupati Banjar Nomor 3 Tahun 2017 dengan Pengelolaan Keuangan Desa pada Pemerintahan Desa Pasar Lama. Penelitian ini menggunakan metode penelitian kualitatif dengan pendekatan analisis deskriptif. Teknik pengumpulan data dilakukan dengan wawancara, observasi, dokumentasi dan studi pustaka. Analisis datanya menggunakan teknik analisis interaktif yaitu melalui pengumpulan data, reduksi data, penyajian data dan penarikan kesimpulan. Hasil penelitian menunjukan bahwa walaupun terdapat adanya kesalahan dalam hal administrasi penyusunan tetapi secara keseluruhan pengelolaan keuangan Desa Pasar Lama sudah hampir sama dengan pengelolaan menurut format Peraturan Bupati Banjar Nomor 3 Tahun 2017.

Kata kunci: pengelolaan keuangan desa, pemerintah desa Pasar Lama, Kecamatan Karang Intan

\section{Latar Belakang}

Berdasarkan UU Nomor 23 Tahun 2014 pasal 1 angka 6, Otonomi daerah merupakan hak, wewenang, dan kewajiban daerah otonom untuk mengatur dan mengurus sendiri urusan pemerintahan dan kepentingan masyarakat setempat dalam sistem Negara Kesatuan Republik Indonesia. Dalam hal ini pemerintah memberikan hak, wewenang dan kewajiban kepada 
masing-masing daerah untuk mampu mengelola apa yang dimiliki oleh daerah tersebut untuk mencapai kesejahteraan masyarakat. Dalam UU Nomor 23 Tahun 2014 tentang pemerintah daerah telah diatur mengenai pelaksanaan sistem desentralisasi di negara Indonesia, dimana pemerintah pusat memberikan kewenangan yang lebih besar kepada daerah untuk melakukan serangkaian proses, mekanisme dan tahap perencanaan yang dapat menjamin keselarasan pembangunan (Thomas,2013). Berdasarkan Peraturan Menteri Dalam Negeri Republik Indonesia Nomor 113 Tahun 2014 tentang Pengelolaan Keuangan Desa, yang disebut Keuangan Desa adalah semua hak dan kewajiban Desa yang dapat dinilai dengan uang serta segala sesuatu berupa uang dan barang yang berhubungan dengan pelaksanaan hak dan kewajiban Desa.

Dalam pengelolaan keuangan desa bersumber dari Alokasi Dana Desa (ADD) dan BUMDes serta sumber pendapatan lainnya pemerintah desa tentu perlu adanya undang-undang yang berfungsi sebagai regulasi, Maka Pemerintah khususnya Pemerintahan Kabupaten Banjar sempat menerbitkan Peraturan Bupati Banjar Nomor 5 Tahun 2015 Tentang Pedoman Pengelolaan Dana Desa yang Bersumber dari Anggaran Pendapatan Belanja dan Negara. Didalam Peraturan ini, terdapat beberapa prinsip dari Pengelolaan itu sendiri, diantaranya Dana Desa yang bersumber dari APBN merupakan bagian yang tidak dapat dipisahan dari pengelolaan keuangan desa yang lainnya yang diatur melalui APBDes. Penggunaan keuangan desa ini juga mengacu pada Rencana Pembangunan Jangka Menengah Desa (RJPMDes) dan Rencana Kerja Pemerintah Desa (RKPDes).

Setelah adanya Peraturan Bupati Banjar Nomor 5 Tahun 2015 Tentang Pedoman Pengelolaan Dana Desa yang bersumber dari APBN ini, yang selanjutnya pada tahun 2017 Pemerintahan Kabupaten Banjar kemudian mengeluarkan lagi peraturan baru yaitu Peraturan Bupati Banjar Nomor 3 Tahun 2017 Tentang Pengelolaan Keuangan Desa. Dimana pada Peraturan kali ini, Pemerintah lebih menekankan lagi pada tahapan-tahapan yangmeliputi Perencanaan, Pelaksanaan, Penatausahaan, Pelaporan dan Pertanggungjawaban. Didalam aspek perencanaan itu sendiri pada Pemerintahan Desa Pasar Lama biasanya melakukan pembuatan terhadap RPJMDes, RKPDes dan APBDes. Yang mana, RPJMDes dan RKPDes merupakan landasan dasardari rencana kegiatan yang akan dilakukan pada tahun berjalan anggaran. Akan tetapi pada tahun 2017 ini, RKPDes masih belum sesuai dengan rencana kegiatan yang telah dilaksanakan Pemerintahan Desa Pasar Lama. Sehingga pada tahun 2017, terjadinya ketimpangan antara RKPDes dengan hasil dari Laporan Realisasi APBDes tahun berjalan.

Yang mana pada tahapan perencanaan di Desa Pasar Lama terdapat 5 (lima) kegiatan dalam pembangunan desa yang dimuat dalam RKPDes (Rencana Kegiatan Pembangunan Desa) hal ini mungkin telah sesuai dengan perencanan awal. Akan tetapi pada tahap selanjutnya, yaitu tahap pelaksanaan yang terbagi menjadi 2 (dua) tahapan pembangunan kegiatan ini terdapat lagi penambahan kegiatan pembangunan desa menjadi 9 (sembilan) kegiatan pembangunan yang awalnya tentu hal ini hampir berbeda dengan usulan perencanaan yang ada terdapat dalam RKPDes (Rencana Kegiatan Pembangunan Desa) yang mana hanya terdapat 5 (lima) kegiatan pembangunan desa saja. Sehingga hal ini tentu saja berdampak terhadap berbedanya hasil antarakesesuaian rencana anggaran peruntukan keuangan desa dengan realita peruntukannya dilapangan.

Pada tahapan penatausahaan, di Pemerintahan Desa Pasar Lama ini Bendahara hanya melakukan pencatatan terhadap 5 Buku Utama yaitu Buku Kas Umum Desa, Buku Bantu Bank Desa, Buku Kas Pembantu Pajak, Buku Pembantu Pendapatan dan Buku Kas Pembantu Kegiatan. Yang mana seharusnya juga ditambah data pendukung lain, diantaranya yaitu Buku Rekapitulasi Panjar Kegiatan, Buku Register SPP Pengeluaran, Buku Register Kwitansi Pembayaran dan Bukti-Bukti pembayaran yang sah. 
Kendala yang sering terjadi pada tahapan Pelaporan dan Pertanggung jawaban di Pemerintahan Desa Pasar Lama adalah sering terlambatnya pelaporan realisasi pelaksanaan APBDesa kepada Bupati baik itu dalam laporan semester pertama dan pada akhir tahun berjalan dan juga terdapatnya kekurangan pencatatan terhadap kegiatan pelaksanaan pembangunan desa pada Realisasi APBDesa tahun 2017.

Dalam masing-masing sub bagian di tahapan-tahapan itu dapat dilihat dengan jelas aturan-aturan yang dimuat tentang Pengelolaan Keuangan Desa yang mana pada Peraturan sebelumnya hanya terdapat tahapan Pelaporan untuk 1 (satu) semester atau tahun berjalannya saja. Akan tetapi, pada Peraturan kali ini pemerintah Khususnya Kabupaten Banjar juga lebih mengedepankan pada aspek pentahapan Perencanaan, Pelaksanaan, Penatausahaan serta Pertanggungjawabannya.

Selama ini ada beberapa masalah muncul yang berkaitan dengan pengelolaan keuangan desa. Pertama, adanya keterlambatan dan kesulitan pemerintah desa dalam penyusunan perencanaan kegiatan dan keuangan desa. Hampir semua perundang-undangan desa yang memerintahkan adanya turunan peraturan melalui Perda dan Perbup. Tindak lanjutnya, Kabupaten Banjar pada tahun 2015 menetapkan peraturan Bupati Banjar Nomor 05 tahun 2015 tentang Pedoman Pengelolaan Dana Desa yang Bersumber Dari Anggaran Pendapatan Belanja Negara, serta pada tahun 2017 yaitu Peraturan Bupati Banjar Nomor 3 Tahun 2017 tentang Pengelolaan Keuangan Desa di Kabupaten Banjar. Turunan dari regulasi-regulasi ini sangat penting untuk membantu kepala desa dan perangkatnya.

Kedua, kurangnya kapasitas dan personalia. Mengelola keuangan desa tidak hanya mengandalkan kuasa kepala desa dan perangkatnya. Tetapi butuh keterlibatan berbagai stakeholders yang ada di desa. Apalagi saat ini desa telah mengelola dana dalam jumlah yang terhitung besar. Untuk itu perlu adanya orang yang mahir dalam menyusun RPJMDesa, RKPDesa, Design dan RAB serta APBDesa. Selama ini, RKPDes dan RAB serta dokumen lainnya disusun asal jadi. Tata cara dan kaidah teknis atau unsur akademis selalu diabaikan sehingga banyaknya dokumen - dokumen yang diperlukan tidak disiapkan dengan matang dan kurang telitinya terhadap dokumen yang disediakan. Yang diutamakan oleh pemerintah desa hanyalah formalitasnya. Soal kebenaran isi, itu urusan kemudian. Bagi mereka yang penting adalah target bisa dicapai.

Ketiga, sistem pengawasan. Pengelolaan keuangan desa masih minim pengawasan dan kurangnya pengetatan terhadap penggunaan anggaran. Fakta lapangan menunjukan bahwa partisipasi publik terhadap pengelolaan keuangan desa masih terbatas dan kurang fokus didalam pengawasannya serta hanya mengandalkan prosedur-prosedur reguler yang masih ada. Sehingga, masih ada pengelolaan keuangan desa yang mungkin belum sepenuhnya dilakukan pengawasan secara menyeluruh.

Penelitian ini memilih objek penelitian di Desa Pasar Lama yang merupakan salah satu desa di Kecamatan Karang Intan Kabupaten Banjaryang menerima dana APBDesa setiap tahunnya.

Berdasarkan latar belakang masalah tersebut, peneliti ingin menganalisa pengelolaan keuangandesa khususnya dalam hal berupa perencanaan, pelaksanaan, penatausahaan, pelaporan serta pertanggung jawaban semua Keuangan Desa pada Pemerintahan Desa Pasar Lama Kecamatan Karang Intan Kabupaten Banjar yang sesuai dengan Peraturan Bupati Banjar Nomor 3 Tahun 2017 tentang Pengelolaan Keuangan Desa di Kabupaten Banjar. Penelitian ini dimaksudkan untuk mengetahui pengelolaan keuangandesa di Desa Pasar Lama Kecamatan Karang Intan dengan cara menganalisa pengelolaan keuangan desa tersebut. 


\section{Kajian Literatur}

Menurut Soetardjo (Thomas:2013) Desa dapat dipahami sebagai suatu daerah kesatuan hukum dimana seseorang bertempat tinggal disuatu masyarakat yang berkuasa (memiliki wewenang) untuk mengadakan pemerintahan sendiri. Pengertian ini menekankan adanya otonomi untuk membangun tata kehidupan desa bagi kepentingan penduduk. Dalam pengertian ini terdapat kesan yang kuat, bahwa kepentingan dan kebutuhan masyarakat desa hanya dapatdiketahui dan disediakan oleh masyarakat desa itu sendiri dan bukan dari pihakluar. Syarat dalam pembentukan sebuah desa yang dicantumkan di Pasal 8 Undang-Undang Nomor 6 Tahun 2014.

Pada Peraturan Menteri Dalam Negeri Nomor 113 Tahun 2014 ini tercantum asas-asas dari Pengelolaan Keuangan Desa sebagai berikut :

1. Keuangan desa yang dihasilkan dikelola berdasarkan asas-asas transparan, akuntabel,partisipatif serta dilakukan dengan tertib dan disiplin anggaran.

a. Asas transparan

Yaitu pengelolaan keuangan desa harus dapat menyajikan informasi secara terbuka dan mudah diakses masyarakat, mulai dari tujuan, sasaran, sumber pendanaan pada setiap obyek/jenis belanja serta korelasi antara besaran anggaran dengan manfaat dan hasil yang akan dicapai dari suatu kegiatan.

b. Asas akuntabel

Yaitu pengelolaan keuangan desa melibatkan seluruh masyarakat semua sehingga masyarakat mengetahui hak dan kewajibannya.

c. Asas partisipatif

Yakni dalam pelaksanaan pengelolaan keuangan desa, tidak hanya tanggung jawab pemerintah desa semata, melainkan menjadi tanggung jawab seluruh masyarakat. Adapun tugas masyarakat mengawasi pengelolaan keuangan desa secara aktif.

d. Tertib dan disiplin anggaran

Yakni dalam pengelolaan keuangan desa mengutamakan kepatuhan dan kesesuaian peraturan - perundangan. Pengelolaan keuangan juga dilakukan secara berkelanjutan.

2. Keuangan desa dikelola dalam masa 1 (satu) tahun anggaran yakni mulai tanggal 1 Januari sampaidengan tanggal 31 Desember. Keuangan Desa khususnya Dana Desa biasanya diprioritaskan untuk membiayai pembangunan dan pemberdayaan masyarakat, yang meliputi :

1. Bidang bidang Pelaksanaan Pembangunan Desa, yang meliputi antara lain :

- Pengadaan, pembangunan, pengembangan dan pemeliharaan sarana prasarana yang merupakan dasar untuk pemenuhan kebutuhan.

- Pengadaan, pembangunan, pengembangan dan pemeliharaan sarana prasarana pelayanan sosial untuk pemenuhan kebutuhan.

- Pengadaan, pembangunan, pengembangan dan pemeliharaan sarana prasarana ekonomi untuk mewujudkan lumbung ekonomi desa yang meliputi usaha ekonomi pertanian untuk ketahanan pangan.

- Pengadaan, pembangunan, pengembangan dan pemeliharaan sarana prasarana lingkungan misalnya kesiapsiagaan menghadapi bencana.

- Pengadaan, pembangunan, pengembangan dan pemeliharaan sarana prasarana lainnya yang sesuai dengan kebutuhan desa dan ditetapkan dalam Musyawarah Desa.

2. Bidang bidang Pemberdayaan Masyarakat Desa, yang meliputi diantaranya :

- Peningkatan partisipasi masyarakat dalam proses perencanaan, pelaksanaan dan pengawasan desa. 
- Pengembangan kapasitas masyarakat desa.

- Pengembangan ketahanan masyarakat desa, dll.

Di dalam Peraturan Bupati Banjar Nomor 5 Tahun 2015 Tentang Pedoman Pengelolaan Dana Desa yang Bersumber Dari Anggaran Pendapatan Belanja Negara. dimuat tata cara pengelolaan keuangan yang bersumber dari Anggaran Pendapatan Belanja Negara yang bagiannya tidak dapat dipisahkan dengan APBDesa itu sendiri. Pengelolaan ini dilaksanakan dengan menggunakan prinsip tertib, taat pada peraturan perundang-undangan, efisien, ekonomis, efektif, transparan, dan bertanggungjawab dengan memperhatikan rasa keadilan dan kepatutan serta mengutamakan kepentingan masyarakat setempat.

Pada penggunaannya biasanya untuk membiayai penyelenggaran pemerintahan desa, pembangunan, pemberdayaan masyarakat dan pembinaan kemasyarakatan. Penggunaan keuangan desa ini juga mengacu pada Rencana Pembangunan Jangka Menengah Desa (RJPMDes) dan Rencana Kerja Pemerintah Desa (RKPDes).

Pencairan dana pada Peraturan Bupati Banjar Nomor 5 Tahun 2015 ini dimulai dengan Pambakal mengajukan permohonan penyaluran dan pencairan kepada Camat dengan melampiri Rencana Penggunaan Desa, Pernyataan tanggungjawab pengunaan Dana Desa, Laporan pengunaan Dana Desa dan surat pertanggungjawaban. Setelah diperiksa oleh Camat dan telah mengajukan rekomendasi permohonan penyaluran dan pencairan Dana Desa kepada BPMPD. Selanjutnya setelah itu, Kepala BPMPD meneruskannya kepada Kepala Badan Pengelola Keuangan dan Aset Daerah (BPKAD) untuk kemudian Kepala BPKAD menyalurkan Dana Desa tersebut dari Kas Daerah ke Rekening Kas Desa.

Untuk sistem Pelaporan dan Pertanggung jawabannya Pambakal disini wajib menyampaikan laporan realisasi penggunaan Dana Desa kepada Bupati Banjar setiap semesternya. Sedangkan untuk sistematika laporan realisasi penggunaan dana desa dijelaskan disini terdiri dari Pendahuluan, Program dan Kegiatan, Pelaksanaan, Permasalahan dan Upaya Pemecahan Masalah, Tindak Lanjut Kegiatan dan Penutup.

Peraturan Bupati Banjar Nomor 3 Tahun 2017 Tentang Pengelolaan Keuangan Desa Dalam Peraturan Bupati Banjar Nomor 3 Tahun 2017 tentang pengelolaan keuangan desa di Kabupaten Banjar ini lebih mendominankan kepada 5 (lima) tahapan pengelolaan keuangan itu sendiri yaitu Tahap Perencanaan, Pelaksanaan, Penatausahaan, Pelaporan dan Pertanggungjawaban Keuangan Desa. Pengelolaan keuangan desa ini dikelola dalam masa 1 (satu) tahun anggaran yakni tanggal 1 Januari sampai dengan tanggal 31 Desember, untuk lebih jelasnya akan dijabarkan sebagai berikut:

1. Perencanaan

Pada tahap perencanaan pembangunan desa didahului dengan Musyawarah Perencanaan

Pembangunan Desa (Musrenbang) dengan melibatkan BPD, LPM, dan tokoh masyarakat lainnya. Selanjuntnya berdasarkan hasil tersebut, Sekretaris Desa menyusun Rancangan

Peraturan Desa tentang APBDesa berdasarkan RKPDesa tahun berkenaan dan setelah itu Sekretaris Desa menyampaikan Rancangan Peraturan Desa tentang APBDesa tadi kepada Kepala Desa dan APBDesa tersebut akan disepakati bersama paling lambat bulan Oktober tahun berjalan.

Kemudian setelah disepakati bersama maka Bupati akan mendelegasikan pelaksanaan evaluasi Rancangan Peraturan Desa tentang APBDesa kepada camat. Bupati melalui Tim Evaluasi Kecamatan menetapkan hasil Evaluasi Rancangan APBDesa paling lama 20 (dua puluh) hari kerja sejak diterimanya Rancangan Peraturan Desa tentang APBDesa tersebut. Jika tidak sesuai dengan kepentingan umum dan peraturan perundang-undangan yang lebih tinggi Pambakal dapat melakukan penyempurnaan paling lama 7 (tujuh) hari kerja terhitung sejak diterimanya hasil evaluasi. 
2. Pelaksanaan

Semua penerimaan dan pengeluaran desa melalui keuangan transfer dalam rangka pelaksanaan kewenangan desa dilaksanakan melalui Rekening Kas Desa dan harus didukung oleh alat bukti yang lengkap dan sah. Pengeluaran desa yang mengakibatkan beban APBDesa tidak dapat dilakukan sebelum Rancangan Peraturan Desa tentang APBDesa ditetapkan menjadi Peraturan Desa. Kecuali belanja pegawai yang bersifat mengikat dan operasional perkantoran yang ditetapkan dalam Peraturan Kepala Desa. Penggunaan biaya tak terduga terlebih dahulu harus dibuat Rincian Anggaran Biaya yang telah disahkan Kepala Desa. Penyetoran dan pengambilan dana dalam Rekening Kas desa biasanya terlebih dahulu ditanda tangani oleh Pambakal setelah diverifikasi oleh Sekretaris Desa dan Bendahara Desa. Dalam hal ini Bendahara Desa dapat menyimpan uang dalam Kas Desa sebesar Rp. 5.000.000,00 (Lima Juta Rupiah) dalam rangka untuk memenuhi kebutuhan operasional pemerintah desa. Berdasarkan rencana anggaran biaya, pelaksana kegiatan akan mengajukan Surat Permintaan Pembayaran (SPP) kepada Pambakal. Surat Permintaan Pembayaran (SPP) ini tidak boleh dilakukan sebelum barang dan atau jasa itu diterima. Pengajuan Surat Permintaan Pembayaran (SPP) terdiri dari :

a. Surat Permintaan Pembayaran (SPP);

b. Pernyataan tanggungjawab belanja;

c. Lampiran bukti transaksi.

Dalam pengajuan pelaksanaan pembayaran, Sekretaris Desa berkewajiban untuk :

a. Meneliti semua kelengkapan permintaan pembayaran yang diajukan oleh para pelaksana kegiatan.

b. Menguji semua kebenaran perhitungan tagihan atas beban APBDesa yang tercantum dalam permintaan pembayaran;

c. Menguji ketersediaan dana untuk kegiatan yang dimaksud;

d. Menolak semua pengajuan permintaan pembayaran oleh pelaksana kegiatan apabila tidak memenuhi persyaratan yang ditetapkan.

3. Penatausahaan

Penatausahaan penerimaan dan pengeluaran biasanya terdiri dari :

a. Buku Kas Umum Desa.

b. Buku Bantu Bank Desa.

b. Buku Kas Pembantu Pajak.

c. Buku Pembantu Pendapatan.

d. Buku Kas Pembantu Kegiatan.

e. Buku Rekapitulasi Panjar Kegiatan.

f. Buku Register SPP Pengeluaran.

g. Buku Register Kwitansi Pembayaran.

h. Bukti-Bukti pembayaran yang sah.

4. Pelaporan

Kepala Desa menyampaikan laporan realisasi pelaksanaan APBDesa kepada Bupati berupa:

a. Laporan semester pertama

Laporan semester pertama berupa laporan realisasi APBDesa. Laporan ini disampaikan paling lambat pada akhir bulan Juli tahun berjalan.

b. Laporan semester akhir tahun

Laporan semester akhir tahun ini biasanya disampaikan paling lambat pada akhir bulan Januari tahun berikutnya. 


\section{Pertanggungjawaban}

Kepala Desa menyampaikan laporan pertanggung jawaban realisasi pelaksanaan APBDesa kepada Bupati setiap akhir tahun anggaran. Laporan pertanggungjawaban realisasi pelaksanaan APBDesa terdiri dari pendapatan, belanja, dan pembiayaan. Laporan pertanggungjawaban realisasi APBDesa ditetapkan dengan Peraturan Desa. Peraturan Desa tersebut disampaikan paling lambat pada akhir bulan Januari tahun anggaran berikutnya. Peraturan Desa tentang pertanggungjawaban realisasi pelaksanaan APBDesa dilampiri :

a. Laporan pertanggungjawaban realisasi pelaksanaan APBDesa tahun anggaran berkenaan;

b. Laporan kekayaan milik per 31 Desember tahun anggaran berkenaan;

c. Laporan program pemerintah dan pemerintah daerah yang masuk ke desa.

Laporan pertanggung jawaban realisasi pelaksanaan APBDesa merupakan bagian tidak terpisahkan dari Laporan penyelenggaraan pemerintahan desa. Laporan realisasi dan laporan pertanggungjawaban realisasi pelaksanaan APBDesa diinformasikan kepada masyarakat secara tertulis dan dengan media informasi yang mudah diakses oleh masyarakat. Media informasi antara lain papan pengumuman, radio komunitas, dan media informasi lainnya.

Laporan realisasi dan laporan pertanggungjawaban pelaksanaan APBDesa disampaikan kepada Bupati melalui camat. Laporan realisasi pelaksanaan APBDesa disampaikan paling lambat 1 (satu) bulan setelah akhir tahun anggaran berkenaan.

Penelitian ini dibangun berdasarkan pada penelitian terdahulu yang telah dilakukan sebagai pijakan penelitian, yaitu :

1. Sri Lestari (2017), dengan judul penelitian "Analisis Akuntabilitas Pengelolaan Alokasi Dana Desa(ADD) di Wilayah Kecamatan Banyudono". Tujuan penelitian ini adalah menganalisis proses pengelolaan Alokasi Dana Desa (ADD) di Wilayah Kecamatan Banyudono. Penelitian ini menggunakan metode deskriptifkualitatif. Penelitian ini mengumpulkan data dengan melakukan observasi, wawancara, dokumentasi dan studi pustaka dengan pejabat terkait pengelolaan Alokasi Dana Desa (ADD). Yang dapat disimpulkan dari penelitian ini adalah :

a. Tahap perencanaan Alokasi Dana Desa (ADD) di 15 (lima belas) desa telah menerapkan prinsip partisipasi dan transparansi. Hal ini dibuktikan dengan kehadiran masyarakat yang sangat antusias dalam forum musyawarah desa. Selain itu dalam musyawarah desa, pemerintah desa terbuka untuk menerimasegala usulan masyarakat yang hadir untuk berjalannya pembangunan di desa terkait.

b. Tahap pelaksanaan program Alokasi Dana Desa (ADD) di Kecamatan Banyudono telah menerapkan prinsip transparansi dan akuntabilitas. Prinsip transparansi terpenuhi dengan adanya informasi yang jelas mengenai jadwal pelaksanaan fisik yang di danai oleh ADD. Untuk prinsip akuntabilitas sudah terlaksana sepenuhnya karena pertanggungjawaban secara fisik danadministrasinya sudah selesai dan lengkap.

c. Tahap pertanggungjawaban Alokasi Dana Desa (ADD) baik secara teknis maupun administrasi sudah baik, namun harus tetap mendapat atau diberikanbimbingan dari pemerintah kecamatan.

2. Riska Apriliana (2017), dengan judul penelitian “Analisis Pengelolaan Dana Desa Dalam Mewujudkan Good Governance (studi kasus Desa Ngombakan Kecamatan Polokarto Kabupaten Sukoharjo)". Tujuan penelitian ini adalah untuk mendeskripsikan dan menjelaskan mengenai pengelolaan keuangan Alokasi Dana Desa (ADD) dalam mewujudkan Good Governance di Desa Ngombakan Kecamatan Polokarto Kabupaten 
Sukoharjo. Penelitian ini menggunakan metode kualitatif. Penelitian ini mengumpulkan data dengan melakukan wawancara, dokumentasi dan observasi dengan pejabat terkait pengelolaan keuangan dana desa. Yang dapat disimpulkan dari penelitian ini adalah :

a. Tahap perencanaan di Desa Ngombakan Kecamatan Polokarto Kabupaten Sukoharjo telah sesuai dengan Permendagri Nomor 113 Tahun 2014 telah sesuai dan sudah dapat dikatakan transparan dan menjunjung tinggi partisipasi masyarakat.

b. Tahap pelaksanaan dan penatausahaan di Desa Ngombakan Kecamatan Polokarto Kabupaten Sukoharjo secara teknis telah 100\% sesuai dengan Permendagri Nomor 113 Tahun 2014.

c. Tahap pertanggungjawaban Desa Ngombakan Kecamatan Polokarto Kabupaten Sukoharjo sudah menggunakan format laporan pertanggung jawaban yang sesuai dengan Permendagri Nomor 113 Tahun 2014.

3. Febrian (2012), dengan judul penelitian “Analisis Pengelolaan Keuangan Desa Lubuk Sakat Dalam Rangka Mewujudkan Pembangunan Desa Lubuk Sakat Tahun 2012”. Tujuan penelitian ini adalah menganalisis Pengelolaan Keuangan Desa serta faktor - faktor yang mempengaruhi Pengelolaan Keuangan Desa Lubuk Sakat Dalam Mewujudkan Pembangunan Desa Lubuk Sakat Tahun 2012. Penelitian ini menggunakan Metode analisis dekriptif. Yang dapat disimpulkan dari penelitian ini adalah:

a. Pengelolaan keuangan Desa Lubuk Sakat secara administratif telah tersusun dan berjalan dengan baik. Proses pengelolaan keuangan itu dimulai dari proses perencanaan, penganggaran, penatausahaan, pelaporan pertanggungjawaban dan pengawasan keuangan. Semua proses itu dilalui oleh Pemerintah Desa Lubuk Sakat dalam mengelola keuangan Desa yang bersumber dari pendaptan asli desa, dana perimbangan, pajak dan retribusi dan sumber lainnya yang tidak mengikat dan sah menurut hukum.

b. Pengelolaan keuangan Desa Lubuk Sakat baik secara administratif akan tetapi tidak baik dari sisi empirik, hal itu dikarenakan banyaknya hambatan - hambatan teknik dalam pengelolaan keuangan Desa Lubuk Sakat. Adapun hambatan - hambatan itu adalah hambatan pendidikan aparatur, alokasi anggaran yang tidak seimbang, fasilitas pendukung, minimnya partisipasi dan pengawasan serta faktor kapasitas desa.

\section{Metode Penelitian}

Jenis penelitian ini adalah penelitian kualitatif dengan pendekatan analisisdeskriptif. Menurut Moleong (2012) mengatakan bahwa penelitian kualitatif adalahpenelitian yang bermaksud untuk memahami fenomena tentang apa yang dinilaioleh subjek penelitian misalnya perilaku, persepsi, motivasi, tindakan dll. Secaraholistik, dan dengan cara deskriptif dalam bentuk kata-kata dan bahasa, padasuatu konteks khusus yang alamiah dan dengan memanfaatkan berbagai metodealamiah. Penelitian kualitatif ini diharapkan mampu menghasilkan hasil penelitianberupa uraian yang mendalam tentang ucapan, tulisan, dan atau perilaku yangdapat diamati dalam suatu konteks tertentu yang dikaji dari sudut pandang yangutuh dan komprehensif.

Penelitian ini juga dilakukan dengan metode analisis deskriptif, yaitu metode yang menggambarkan secara utuh dan mendalam tentang realitas sosial dan berbagai fenomena yang terjadi di masyarakat yang menjadi subyek penelitian, sehinga tergambarkan ciri, karakter, sifat dan model dari fenomena tersebut. Penelitian ini bertujuan untuk memperoleh gambaran secara lengkap dan detail tentang kejadian dan fenomena yang terjadi pada obyek sehingga menggambarkan secara utuh fenomena yang terjadi (Wida,2016: 39). Metode ini bertujuan untuk mendeskripsikan data yang terkumpul secara sistematis dan akurat sehingga dengan menggunakan metode ini, diharapkan penulis dapat menggambarkan keadaan dengan jelas dan 
terinci mengenai penerapan pengelolaanKeuangan Desa pada Pemerintahan Desa Pasar Lama Kecamatan Karang Intan Kabupaten Banjar.

Data yang digunakan dalam penelitian ini terbagi menjadi data primer dan data sekunter, yaitu:

1. Data Primer

Data primer menurut Sanusi (2014:104) adalah data yang pertama kalidicatat dan dikumpulkan oleh peneliti. Peneliti dapat mengontroltentang kualitas data tersebut, dapat mengatasi kesenjangan waktuantara saat dibutuhkan data itu dengan yang tersedia, dan penelitilebih leluasa dalam menghubungkan masalah penelitiannya dengankemungkinan ketersediaan data di lapangan. Di dalam penelitian inidata primer diperoleh melalui wawancara langsung kepada pihak yangberkompeten dalam pengelolaan Keuangan Desa diPemerintahan Desa Pasar Lama Kecamatan Karang Intan Kabupaten Banjar.

2. Data sekunder

Menurut Sanusi (2014:104), data sekunder adalah data yang sudahtersedia dan dikumpulkan oleh pihak lain. Peneliti tinggalmemanfaatkan data tersebut menurut kebutuhannya. Data sekunderpenelitian ini diperoleh dari dokumen-dokumen Bagian PemerintahanDesa Pasar Lama Kecamatan Karang Intan Kabupaten Banjar.

Teknik pengumpulan data yang digunakan dalam penelitian ini meliputi :

1. Wawancara

Untuk mengumpulkan data dan informasi yang valid dan akurat, pengumpulandata yang utama (untuk mendapatkan data primer) peneliti akan melakukanwawancara langsung secara mendalam kepada informan yang kompeten dalampengelolaan Keuangan Desa, mencatat kejadian serta informasi dariinforman yang kemudian dijadikan sebagai bahan penulisan laporan hasil penelitian.Informan yang kompeten dalam pengelolaan Keuangan Desa yaitu orang yang memiliki pengetahuan atau sebagai partisipan untuk menggali informasidan memiliki kemampuan untuk melaksanakan suatu pekerjaan atau tugas yangdilandasi oleh keterampilan dan pengetahuan kerja sesuai dengan bidangnya masingmasing. Informan yang diwawancarai adalah diantaranya seluruh Kepala Desa, Sekertaris, Bendahara dan Kaur Keuangan.

2. Observasi

Observasi diartikan sebagai pengamatan dan pencatatan secara sistematikterhadap gejala yang tampak pada objek penelitian. Menurut Sutrisno Hadi (2013 :145)“"Teknik observasi merupakan suatu proses yang komplek, suatu proses yang tersusun dari berbagai proses biologis dan psikhologis. Dua diantara yang terpenting adalah proses-proses pengamatan dan ingatan". Dalam hal ini, peneliti melakukan pengamatan secara langsung ke lokasi penelitian yaitu di Pemerintahan Desa Pasar Lama Kecamatan Karang Intan Kabupaten Banjar.

\section{Dokumentasi}

Menurut Sugiyono (2013 :240), "Dokumentasi merupakan catatan peristiwayang sudah berlalu". Jadi dokumen merupakan bahan tertulis yang berhubungandengan suatu peristiwa atau aktivitas tertentu. Dokumen yang digunakan dalampenelitian ini adalah informasi yang disimpan atau didokumentasikan sepertidokumen, data soft file, data otentik, foto dan arsip lainnya yang berkaitan denganpenyusunan laporan keuangandesa di Desa Pasar Lama yangdapat digunakan sebagai data pelengkap dari data yang diperoleh dalam kegiatan wawancara dan observasi. 


\section{Studi Pustaka}

Yaitu Teknik pengumpulan data yang dilakukan dengan mempelajari buku-bukureferensi, laporan-laporan, majalah-majalah, jurnal-jurnal dan media lainnyayang berkaitan dengan masalah yang diteliti.

Teknik analisis data dari penelitian ini dengan analisis komparatif. Analisis komparatif adalah teknik analisis yang dilakukan dengan cara membuat perbandingan antar elemen yang sama, seperti penelitian ini yang membandingkan antara pengelolaan keuangan desa Pasar Lama dengan standar - standar yang mengacu pada Peraturan Bupati Banjar Nomor 3 Tahun 2017 tentang Pengelolaan Keuangan Desa. Langkah awal sebelum melakukan analisis data, peneliti perlu memahami teori pada Peraturan Bupati Banjar Nomor 3 Tahun 2017. Selanjutnya setelah peneliti memahami teori Pengelolaan Keuangan Desa menurut Peraturan Bupati Banjar Nomor 3 Tahun 2017 perlu dilakukan analisis dengan menggunakan data - data yang telah didapatkan. Data yang telah didapatkan dari penelitian ini merupakan data kualitatif hasil dari wawancara, analisis dokumentasi, observasi dilapangan dan perbandingan studi pustaka. Langkah-langkah dalam melaksanakan penelitian ini adalah sebagai berikut:

1. Pengumpulan data, dimana peneliti mencatat data yang diperoleh sesuai dengan hasil wawancara, observasi dan dokumentasi dilapangan. Pada tahap awal ini, data yang dikumpulkan berupa RPJMDes, RKPDesa, Laporan Penatausahaan dan APBDesa.

2. Reduksi data, dimana peneliti merangkum dan memilih informasi inti yang sesuai dengan fokus penelitian. Pemilihan dan perangkuman data dilakukan apabila data yang diperoleh dari narasumber terlalu banyak dan takutnya tidak semua relevan dengan rumusan masalah. Reduksi data dilakukan untuk menghasilkan data yang lebih tepat dan jelas serta mempermudah peneliti untuk melakukan pengumpulan data yang selanjutnya, dan mencari kembali ketika dibutuhkan oleh peneliti.

3. Penyajian data yang dilakukan dalam bentuk uraian singkat sehingga dapat mempermudah peneliti untuk memahami kondisi yang terjadi dan dapat menentukan tahap selanjutnya yang akan dikerjakan. Data yang dapat disajikan oleh peneliti dalam penelitian ini berupa analisis perencanaan pengelolaan keuangan desa.

4. Analisis data, yaitu dengan menganalisis kesesuaian dokumen-dokumen terkait antara pengelolaan keuangan desa pada Pemerintahan Desa Pasar Lama dengan pengelolaan keuangan desa menurut Peraturan Bupati Banjar Nomor 3 Tahun 2017 tentang Pengelolaan Keuangan Desa.

5. Perumusan dalam simpulan, yakni dengan melakukan tinjauan ulang dilapangan untuk menguji kebenaran dan validitas makna yang munculdisana. Hasil yang diperoleh diinterpresentasikan, kemudian disajikandalam bentuk naratif.

\section{Hasil Penelitian}

Pengelolaan keuangan desa di Pemerintahan Desa Pasar Lama yang selama ini belum mengacu pada tahapan - tahapan pengelolaan keuangan, diantaranya:

1. Perencanaan

a. Rencana dalam Kegiatan Pemerintahan Desa (RKPDes)

Perencanaan kegiatan di Desa Pasar Lama dimulai dari kegiatan Rapat Desa untuk menentukan kegiatan yang akan dilakukan pada 1 (satu) tahun kedepan yang biasanya akan menyimpulkan dalam bentuk RKPDes. RKPDes ini merupakan dasar dari pemerintahan desa dalam melaksanakan kegiatannya selama 1 (satu) tahun berjalan. Rencana Kegiatan Pemerintahan Desa (RKPDes) di Pemerintahan Desa Pasar Lama disusun dan disahkan pada tanggal 21 Maret 2016. Setelah adanya RKPDes tersebut maka sekretaris desa kemudian menyusun Rancangan Peraturan Desa tentang APBDes 
berdasarkan RKPDes yang telah dibuat tadi. Kemudian selanjutnya, sekretaris desa menyampaikan ke Kepala Desa yang setelah itu disepakati bersama pada Tanggal 10 Januari 2017.

\section{b. Rencana Anggaran Biaya}

Pada dasar Rencana Anggaran Biaya yang dijelaskan di Bab Hasil Penelitian terlihat dengan jelas adanya Rencana Anggaran Biaya tiap rencana kegiatan pembangunan di Desa Pasar Lama, yang mana Rencana Anggaran Biaya tadi terdapat 5 (lima) kegiatan yang akan dilaksanakan pertahun berjalan atau pada tahun 2017. Rencana Anggaran Biaya ini disusun untuk memenuhi persyaratan guna kemudahan dalam melakukan perincian keuangan akan kegiatan terhadap pembangunan di Desa Pasar Lama. Rencana Anggaran Biaya ini disusun dan dilampirkan di RKPDes. Sehingga didalam RKPDes juga ada Rencana Anggaran Biaya (RAB) yang telah disepakati bersama oleh Pemerintahan Desa Pasar Lama.

\section{c. Usulan Anggaran APBDes}

Setelah disepakati bersama pada tanggal 10 Januari 2017, APBDes tersebut selanjutnya Bupati akan mendelegasikan pelaksanaan evaluasi Rancangan Peraturan Desa tentang APBDes kepada Camat. Kemudian Bupati melalui Tim Evaluasi Kecamatan akan menetapkan hasil evaluasi tersebut. Dan hasil tersebut merupakan akan menjadi Peraturan Desa tentang APBDes yang akan dijalankan pada tahun berjalan 2017 tersebut. Setelah adanya APBDes tadi maka Pemerintahan Desa Pasar Lama Kemudian melakukan Musyawarah lagi untuk menentukan TPK (Tim Pelaksana Kegiatan) yang biasanya terdiri dari Ketua dan 2 (dua) orang anggotanya. TPK ini merupakan Tim Pelaksana Kegiatan yang mana tugasnya adalah untuk memonitor setiap kegiatan yang akan dilakukan oleh desa tadi berdasarkan APBDes. Dan kemudian, pada Tanggal 20 Januari 2017 TPK disahkan Oleh Pambakal Desa Karang Intan.

\section{Pelaksanaan}

Pada tahap pelaksanaan yang selama ini terjadi di Pemerintah Desa Pasar Lama melakukan kegiatan penerimaan dan pengeluaran desa melalui Rekening Kas Desa yang langsung dipegang sendiri oleh Bendahara Desa. Bendahara Desa pun hanya diperbolehkan menyimpan uang Kas sebanyak Rp. 5.000.000,- (lima juta rupiah) saja untuk memenuhi kebutuhan operasional pemerintahan desa.

Pada penyetoran dan pengambilan dana dalam Rekening Kas desa terlebih dahulu ditanda tangani oleh Pambakal dan harus selalu diverifikasi oleh Sekretaris Desa dan Bendahara Desa. Untuk masalah pengajuan pendanaan kegiatan Pemerintahan Desa biasanya menyertai sebuah dokumen seperti Rencana Anggaran Biaya (RAB) yang telah diverifikasi dan Surat Pernyataan Pembayaran (SPP) yang dibuat oleh TPK.

Saat melakukan pelaksanaan kegiatan ini Pemerintah Desa sesuai dengan RKPDes mempunyai 5 (lima) kegiatan untuk Pembangunan Desa, akan tetapi pada saat dilapangannya terdapat perubahan menjadi 9 (sembilan) kegiatan. Hal ini akhirnya menjadikan sebuah kerancuan administrasi, yang mana harusnya 4 (empat) dari 9 (sembilan) kegiatan inipun juga tersimpulkan di RKPDes.

Dengan adanya perubahan ini tentu membuat RKPDes tidak sesuai atau mungkin kesalahan dalam administrasi karena adanya perubahan dalam hal pembangunan desa tersebut.

Dan juga dengan adanya penambahan kegiatan tersebut pula, 4 (empat) dari 9 (sembilan) tersebut belum tersedianya Rencana Anggaran Biaya (RAB) awal yang biasanya terdapat di 
RKPDes. Hal ini tentu menjadi masalah untuk Pemerintahan Desa Pasar Lama yang mana harusnya setiap kegiatan diharuskan adanya Rencana Anggaran Biayanya.

\section{Penatausahaan}

Pada tahap penatausahaan yang selama ini terjadi di Pemerintahan Desa Pasar Lama, Bendahara hanya melakukan kegiatan pencatatan penerimaan dan pengeluaran keuangan desa pada 5 (lima) buku saja, yaitu yang terdiri dari Buku Kas Umum, Buku Kas Tunai, Buku Kas Pembantu Bank dan Buku Pembantu Pajak. Akan tetapi seharusnya Bendahara juga harus melengkapi pada buku - buku yang lainnya juga. Yang mana dengan adanya buku tersebut juga pasti berkaitan langsung dengan jalannya pengelolaan keuangan desa yang baik dan benar. Sehingga tentu akan sangat bermanfaat dalam mencapai efektivitas dalam pengelolaan keuangan desa. Buku - buku yang selama ini masih belum dilakukan pencatatan pada Pemerintahan Desa Pasar Lama diantaranya :

- Buku Rekapitulasi Panjar Kegiatan

- Buku Register SPP Pengeluaran

- Buku Register Kwitansi Pembayaran

\section{Pelaporan}

Di tahapan pelaporan yang terjadi dalam pengelolaan keuangan desa pada Pemerintahan Desa Pasar Lama telah sepenuhnya dipenuhi. Yang mana pada akhir bulan Julitahun 2017pemerintahan Desa Pasar Lama telah melaporkan Laporan Semester Pertama.

Dan pada akhir bulan Januari tahun 2018 pemerintahan Desa Pasar Lamapun juga telah melaporkan pula Laporan Semester Akhir Tahun kepada Bupati yang bersangkutan. Sehingga tentu dengan telah di penuhinya pelaporan ini berarti tahapan pelaporan pada pengelolaan keuangan desa Pasar Lama telah sesuai dengan Peraturan Bupati Banjar Nomor 3 Tahun 2017.

\section{Pertanggungjawaban}

Tahap pertanggungjawaban yang selama ini dilakukan oleh Pemerintahan Desa Pasar Lama adalah Pambakal telah menyampaikan laporan pertanggungjawaban realisasi pelaksanaan APBDes kepada Bupati melalui Camat di akhir tahun anggaran. Laporan pertanggungjawaban realisasi APBDes ini terdiri dari pendapatan, belanja dan pembiayaan. Laporan tersebut disahkan menjadi Peraturan Desa tentang Realisasi Pelaksanaan APBDes yang ditetapkan pada Tanggal 30 Januari 2019.

Pengelolaan Keuangan Desa di Pemerintahan Desa Pasar Lama Kecamatan Karang Intan Yang Sesuai Dengan Peraturan Bupati Nomor 3 Tahun 2017 Tentang Pengelolaan Keuangan Desa.

\section{Perencanaan}

a. Rencana program Kegiatan Pemerintahan Desa (RKPDes)

Pada tahap awal dalam perencanaan ini seharusnya Desa lebih memperhatikan lagi dalam pembuatan RKPDes. Karena RKPDes adalah merupakan dasar perumusan dalam pembangunan dan perencanaan kegiatan desa. Yang mana, pada tahun 2017 di RKPDes terdapat 5 (Lima) kegiatan pembangunan desa. Akan tetapi pada saat pelaksanaannya malah terdapat penambahan pada 4 (empat) kegiatan pembangunan desa tersebut. Seharusnya pemerintahan desa Pasar Lama pada tahap perencanaanini harus lebih memikirkan lagi kegiatan apa yang akan dijalankan untuk 1 (satu) tahun berjalan. Agar mungkin tidak menimbulkan kerancuan antara RKPDes dengan Laporan di akhir periode tahun berjalan. 
b. Rencana Anggaran Biaya

Bagaimana telah dijelaskan diatas, adanya penambahan terhadap 4 (empat) kegiatan ini juga tentu berdampak pada ketidakadaannya Rencana Anggaran Biaya (RAB) terhadap 4 (empat) kegiatan yang ditambahkan tadi. Sehingga dapat menimbulkan kerancuan terhadap pelaksanaan 4 (empat) kegiatan tersebut.

Sebaiknya Desa melakukan Perancanganan Pula terhadap 4 (empat) kegiatan yang belum adanya Rencana Anggaran Biaya (RAB). Agar data dalam pemerintahan Desa akan menjadi lebih baik lagi dan tentu pasti berdampak untuk meminimalisir kerancuan tersebut.

c. Usulan Anggaran APBDes

Berdasarkan Peraturan Bupati Nomor 3 Tahun 2017 Usulan Anggaran APBDes merupakan rencana keuangan tahunan pemerintah desa yang dibahas dan disetujui oleh Pemerintah Desa dan BPD, dan harus ditetapkan sebagai Peraturan Desa.

Didalam Usulan Anggaran ini sebaiknya lebih diperhatikan lagitentang apa saja yang akan menjadi tolakukur kegiatan pembangunan yang akan dilakukan Desa sehingga kedepannya Pemerintahan Desa Pasar Lama dalam pengelolaan keuangan desa menjadi lebih baik lagi dalam hal apa saja yang dibutuhkan oleh desa itu sendiri baik dari segi pembangunan ataupun yang lainnya.

2. Pelaksanaan

Pada tahap pelaksanaan ini sesuai dengan Peraturan Bupati Banjar Nomor 3 Tahun 2017 Tentang Pengelolaan Keuangan Desa, seharusnya desa menyesuaikan pelaksanaan kegiatan yang akan dilaksanakan dalam pembangunan desa dalam hal ini pada RKPDes yang merupakan dasar dalam tahap pelaksanaan kegiatan tersebut.

Jadi dalam tahap pelaksanaan ini, desa seharusnya lebih memperhatikan kegiatan pembangunan dalam RKPDes yang menjadi dasar acuan. Sehingga tentu seharusnya RKPDes disesuaikan dengan apa saja kegiatan pembangunan yang dilakukan. Dalam hal ini, terdapat 5 (lima) kegiatan dalam RKPDes tetapi dalam pelaksanaannya terdapat penambahan 4 (empat) kegiatan. Sebaiknya, untuk tidak menimbulkan kerancuan lebih lagi pemerintahan desa Pasar Lama melakukan perbaikan terhadap RKPDes dengan menambahkan lagi 4 (empat) kegiatan yang sudah dilakukan pembangunan desa tersebut, baik dalam usulan anggarannya ataupun rencana anggaran biayanya.

\section{Penatausahaan}

Tahapan penatausahaan yang selama ini telah sesuai dengan Peraturan Bupati Banjar Nomor 3 Tahun 2017 Tentang Pengelolaan Keuangan Desa. Akan tetapi sebaiknya Pemerintahan Desa Pasar Lama harus lebih melengkapi lagi pencatatan terkait penerimaan dan pengeluaran pengelolaan keuangan desa. Seperti Buku Rekapitulasi Panjar Kegiatan, Buku Register SPP Pengeluaran dan Buku Register Kwitansi Pembayaranyang harus dilakukan pencatatan juga.

Buku Rekapitulasi Panjar adalah buku pembantu yang berguna untuk mencatat pengeluaran dan penerimaan yang diberikan pada pihak tertentu dalam sebuah kegiatan. Dalam hal pengeluaranadalah berupa kas tunai, dalam hal penerimaan kas bisa kas tunai bisa sisa panjar atau berupa SPJ dari pihak yang menerima panjar.Buku Register SPP Pengeluaran berguna untuk melakukan kegiatan pencatatan terhadap Surat Pernyataan Pembayaran (SPP) yang dilakukan dalam 1 (satu) periode. Sedangkan, Buku Register Kwitansi Pembayaran berguna untuk mengetahui dan mencatat kwitansi apa saja yang telah kita lakukan pembayaran pada 1 (satu) periode. 


\section{Pelaporan}

Pada tahap pelaporan ini telah sesuai dengan Peraturan Bupati Banjar Nomor 3 Tahun 2017 Tentang Pengelolaan Keuangan Desa. Yang mana Pemerintahan Desa Pasar Lama pada akhir bulan Juli 2017 telah membuat dan melakukan pelaporan terhadap Laporan Semester Pertama. Dan pada akhir bulan Januari tahun 2018 Pemerintahan Desa Pasar Lamapun juga telah melaporkan pula Laporan Semester Akhir Tahun kepada Bupati yang bersangkutan.

\section{Pertanggungjawaban}

Dan pada tahapan pertanggung jawaban di Pemerintahan Desa Pasar Lama telah sesuai dengan Peraturan Bupati Banjar Nomor 3 Tahun 2017 Tentang Pengelolaan Keuangan Desa. Dimana dalam pertanggung jawabannya telah dilakukan perumusan terhadap Peraturan Desa tentang Realisasi APBDesa tahun 2017. Dan pada pemerintahan Desa Pasar Lama pun telah melakukan transparansi kepada warga masyarakatnya dengan adanya spanduk besar yang berada di tiap RT yang mana menggambarkan tentang Realisasi APBDesa tahun 2017 tersebut.

Disaat melaporkan pertanggungjawaban ini terdapat adanya 1 (satu) kegiatan yang belum tercatat pada realisasi APBDesa tahun 2017yang mana sebaiknya Pemerintahan Desa Pasar Lama lebih cermat lagi dalam meneliti dan juga mencermati apakah realisasi APBDesa yang telah dilaksanakan dilapangan telah sesuai dengan pelaporan yang telah disampaikan. Tentunya dengan begitu juga pasti akan berdampak pada pengelolaan keuangan desa di Desa Pasar Lama.

\section{Diskusi}

Berdasarkan hasil penelitian dan pembahasan, maka dapat disimpulkan bahwa implikasi hasil penelitian ini adalah:

1. Pemerintahan Desa Pasar Lama Kecamatan Karang Intan Kabupaten Banjar dalam melakukan kegiatan pengelolaan keuangan desa khususnya di tahap perencanaan, pelaksanaan dan penatausahaan belum sepenuhnya sesuai dengan Peraturan Bupati Banjar Nomor 3 Tahun 2017, hal ini dapat dilihat dari adanya penambahan terhadap kegiatan pembangunan desa di tahap perencanaan dan tahap pelaksanaan kegiatan tersebut. Selain itu, ditahap penatausahaan juga terdapat tidak dilakukannya pencatatan buku yang sesuai dengan peraturan diatas.

2. Bagi pemerintahan Desa Pasar Lama Kecamatan Karang Intan Kabupaten Banjar, hasil penelitian ini dapat memberikan masukan dan juga saranuntuk lebih cermat dan teliti lagi dalam menganalisa pengelolaan keuangan desa agar sesuai dengan Peraturan Bupati Banjar Nomor 3 Tahun 2017.

\section{Kesimpulan dan Keterbatasan Penelitian}

Pengelolaan keuangan desa di Pemerintahan Desa Pasar Lama Kecamatan Karang Intan Kabupaten Banjar Tahun 2017, dapat diambil kesimpulan sebagai berikut :

1. Pengelolaan keuangan desa yang telah dilakukan selama ini oleh Pemerintahan Desa Pasar Lama yang mana dimulai dari tahap perencanaan, pelaksanaan, penatausahaan, pelaporan serta pertanggung jawaban masih didapati adanya kesalahan dalam hal administrasi yang mana pada tahap perencanaan terdapat 5 (lima) pembangunan desa tetapi setelahnya ditahap pelaksanaan terdapat penambahan menjadi 9 (sembilan) kegiatan desa. Yang mana itu berarti terdapat perbedaan diantara tahap perencanaan dan tahap pelaksanaan. Dan juga pada tahap penatausahaan terdapat beberapa buku yang belum dilakukan pencatatan yang tentu akan berdampak pula pada tata kelola keuangan desa tersebut. 
2. Pengelolaan keuangan desa di Pemerintahan Desa Pasar lamasebenarnya sudah hampir sesuai dengan Peraturan Bupati Banjar Nomor 3 Tahun 2017 Tentang Pengelolaan Keuangan Desa, akan tetap sebaiknya Pemerintahan Desa lebih memperhatikan lagi kesesuaian antara tahap perencanaan yang dimaksud adalah RKPDes dengan tahap pelaksanaan yang terdapat kerancuan dalam pembangunan desa. Juga untuk tahap penatausahaan pemerintahan desa Pasar Lama khususnya bendahara sebaiknya pun melakukan juga pencatatan terhadap buku - buku yang belum dilakukan pencatatan sesuai dengan Peraturan Bupati Banjar Nomor 3 Tahun 2017 Tentang Pengelolaan Keuangan Desa.

Berdasarkan keterbatasan peneliti, maka saran dari penelitian ini yaitu :

1. Pemerintahan Desa Pasar Lama diharapkan lebih giat lagi dalam pencapaian realisasi kegiatan dan kelengkapan berkas administratif sehingga diharapkan pemerintah desa dapat meningkatkan kualitas kegiatan serta peningkatan kapasitas perangkat desa dan masyarakat.

2. Pemerintahan Desa Pasar Lama diharapkan agar mengawasi dan melaksanakan pengelolaan keuangan desa dengan baik agar hasil yang didapat lebih maksimal serta menggali lagi potensi yang ada di desa.

3. Pemerintahan Desa Pasar lama diharapkan untuk bisa lebih menyesuaikan lagi antara RKPDes dengan hasil pelaksanaan kegiatannya. Sehingga dengan hasil yang telah sesuai tersebut pemerintahan Desa Pasar Lama dapat terhindar dari adanya perbedaan mendasar antara RKPDes dengan hasil kegiatannya agar pengelolaan keuangan desapun dapat lebih tercapai efektivitasnya.

4. Masyarakat untuk lebih aktif berpartisipasi dan ikut serta dalam melakukan pengawalan terhadap kegiatan pengelolaan keuangan desa. Hal tersebut biasanya dilakukan dengan membuka forum - forum dialog antara pemerintah desa dengan masyarakat atau bisa juga dilakukan dengan kerjasama antara pemerintah desa dan lembaga kemasyarakatan lainnya untuk menjalin komunikasi dengan masyarakat. Dengan cara tersebut, secara tidak langsung dapat merangsang partisipasi masyarakat dalam menyuarakan aspirasi mereka, sehingga masyarakat ikut andil dalam mensukseskan pelaksanaan keuangan desa.

\section{DAFTAR PUSTAKA}

Apriliana, Riska, 2017. Pengelolaan Alokasi Dana Desa Dalam Mewujudkan Good Governance, http///www.eprints.iain-surakarta.ac.id>Skripsi/ (diakses tanggal 06 September 2018)

Arif,Muhammad 2012.Tata Cara Pengelolaan Keuangan Desa Dan Pengelolaan Kekayaan Desa Pekanbaru.

Febrian, 2012. Analisis Pengelolaan Keuangan Desa Lubuk Sakat Dalam Mewujudkan Pembangunan Desa Lubuk Sakat Tahun 2012, http//jom.unri.ac.id/index.php/JOMFSIP/article/view/3214(diakses tanggal 06 September 2018)

Lestari, Sri, 2017. Analisis Akuntabilitas Pengelolaan Alokasi Dana Desa(ADD) di Wilayah Kecamatan Banyudono, http///www.eprints.iain-surakarta.ac.id/256/1/14.Sri Lestari.pdf (diakses tanggal 03 September 2018)

Peraturan Menteri Dalam Negeri Republik Indonesia Nomor 113 Tahun 2014 Tentang Pengelolaan Keuangan Desa.

Peraturan Daerah Kabupaen Banjar Nomor 5 Tahun 2015 Tentang Pedoman Pengelolaan Dana Desa yang Bersumber Dari Anggaran Pendapatan Belanja Negara.

Peraturan Bupati Banjar Nomor 3 Tahun 2017 Tentang Pengelolaan Keuangan Desa di Kabupaten Banjar.

Undang - Undang Republik Indonesia Nomor 6 Tahun 2014 Tentang Desa. 